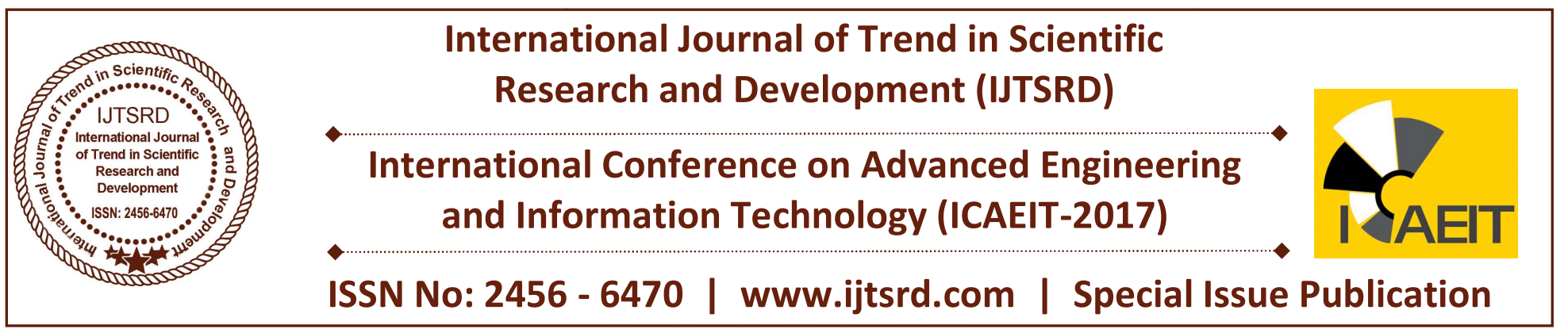

\title{
Determining Coefficient of Discharge and Coefficient of Roughness for Short Grass Bed and Concrete Bed
}

\author{
Choong Pei Kee \\ Faculty of Engineering and \\ Quantity Surveying, INTI \\ International University, \\ Nilai, Malaysia
}

\author{
Deepak T J \\ Associate Professor, Dean, Faculty \\ of Engineering and Technology, \\ Linton University College, \\ Mantin, Nilai, Malaysia
}

\author{
Raman Bai \\ Professor, \\ Faculty of Built Environment, \\ Linton University College, \\ Mantin, Nilai, Malaysia
}

\begin{abstract}
This study carried out to determine the coefficient of discharge and coefficient of roughness for short grass bed and concrete bed in an open channel at Hydraulics laboratory. The open channel on the hydraulic bench is intended to depict an actual open channel flow scenario; therefore steady flow was used for this experiment. From the investigation, it was evident that coefficient of discharge for grass bed and concrete bed ranges between 0.00218 and 0.0539 . The slope of the channel was found to have no effect on coefficient of discharge. Manning's Roughness Coefficient " $n$ " was found to increase with the decrease of discharge. Concrete bed has higher coefficient of discharge and lower coefficient of roughness when compared to short grass.
\end{abstract}

Keywords: Coefficient, Discharge, Roughness, Manning's, Grass Bed, Concrete Bed.

\section{INTRODUCTION}

Nowadays, roughness characteristics in an open channel were widely used in designing such as canals, sewer, dams and more. Dam design, irrigation and drainage network planning, flood simulation, sediment transport, urban water supplies are based on reliable flow measurements. By using the manning equation, it can determine the average velocity of a fluid in an open channel. The $n$ value is the coefficient of roughness that applied to the uniform flow in open channels. However, recent studies shown the coefficient is not constant.
The objective of this experiment is to determine and compare the coefficient of discharge and the coefficient of roughness for different materials with different slope gradient. Hydraulic engineering design work and water assets project play an important role in the human life. By determining the flow of a liquid, a man-made design can be constructed and designed to improve the human lives.

\subsection{Objectives}

The objectives of this study are: -

1. To determine and compare the coefficient of discharge for lined (Concrete) and unlined (Short Grass) channel.

2. To determine and compare the coefficient of roughness for lined (Concrete) and unlined (Short Grass) channel with different slope gradient.

3. To investigate the relationship between coefficient of roughness and discharge in an open channel.

\section{Literature Review}

\subsection{Open Channel Types}

There are many types of open channel flow application around us in our daily life. Such as canals, drainage, ditches, sewers, gutters along the roads, small rivulets and sheets of water are the example of open channel flow which were designed by human. In the other hand, the examples of natural open channel flow are chutes, natural drainage of water through river (Mustaffa and Admad 2016). 
Channels that are designed by engineers where the embankments are strengthened and constructed with concrete are known as lined channel. Where unlined channel is naturally formed with loose embankments. Lined channel is a stable channel section that are mainly used for preventing the water seeping into the ground in order to achieve water conservation. Also, it is used for water supplies and irrigation whereby improving the irrigation facilities in the irrigation areas.

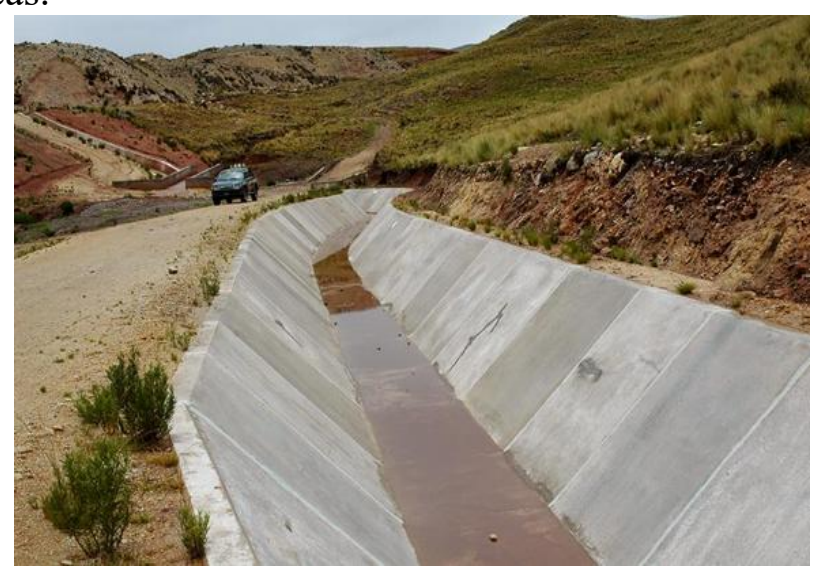

Figure 1 Lined Channel

(Source:.dreamstime.com/canals)

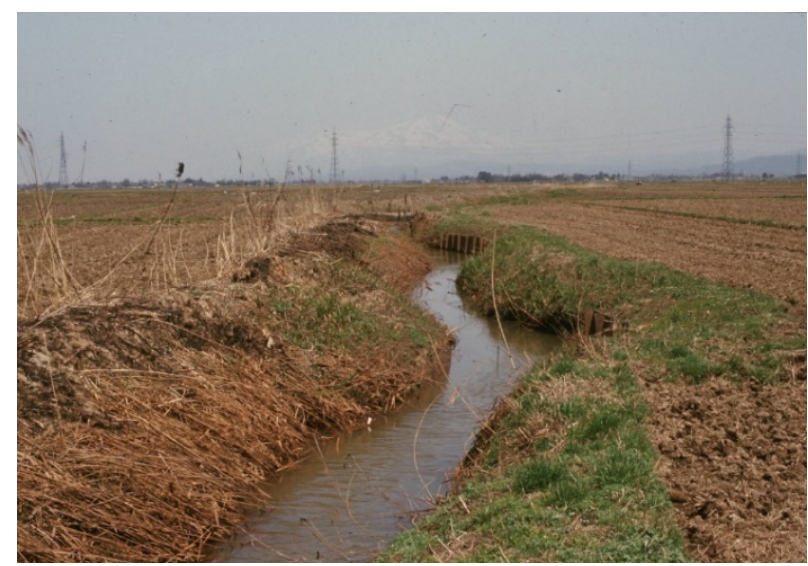

Figure Error! No text of specified style in document.. Unlined Channel

(Source:.dreamstime.com/canals)

\subsection{Flow Types}

There are 2 types of liquid flow which are open channel flow and closed conduit flow. Closed conduits flow is widely known as pipe flow where the top part of the channel where the flow is taking place is closed, for example pipes. Where open channel flow referred as the flow of liquid exposed to the atmosphere like rivers, canals and tunnels. It has a free surface which is subjected to atmospheric pressure while pipe flow does not have free surface is subjected to hydraulic pressure only.

\subsection{Coefficient of Discharge}

Coefficient of discharge is the flow and pressure that in the fluid systems or fluid mechanics. Coefficient of discharge is determined by the ratio of the actual discharge to the theoretical discharge such as the ratio of the mass flow rate at the discharge of the channel to ideal channel. In hydrology, it is defined as $\mathrm{C}_{\mathrm{d}}$ and it is dimensionless and can be expressed as:

$$
\mathrm{C}_{\mathrm{d}}=\frac{\text { Actual Q }}{\text { Theoritical Q }}
$$

There are many types of notch and weirs can be used to determine the coefficient of discharge such as sharp-crested weir, broad-crest weir, and rectangular weir (Kiumars Badr and Daruysh Mowla, 2014).

Weirs are an easy structure to measure the coefficient of discharge and give out more accurate discharge value than flumes and orifices. It is a standard and simplest form of device as the experiment for measurement of water in an open channel. Rectangular weir can be defined as a huge rectangular orifice in which the weir equation can be obtained by adjusting the orifice discharge in the streams.
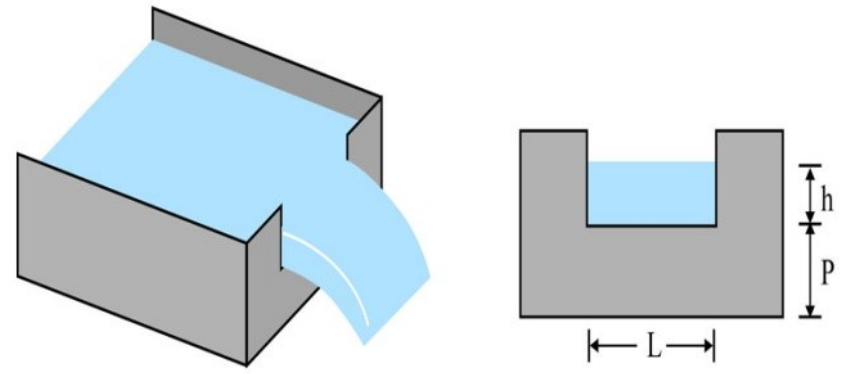

Figure 3: Rectangular Weir

$\mathrm{H}=$ Height of water above sill of notch

$\mathrm{b}=$ Width or length of the notch

$\mathrm{P}=$ Crest Height

Flumes are used to measure flow rate which also known as discharge in open channels. They typically have widths from a few $\mathrm{cm}$ to about $15 \mathrm{~m}$. The water depth in the approach section of flumes typically can be between a few $\mathrm{cm}$ to about $2 \mathrm{~m}$. Flumes has the advantage of less head loss through the device, but it is more complicated to construct and more difficult to analyze as compared to weirs. 


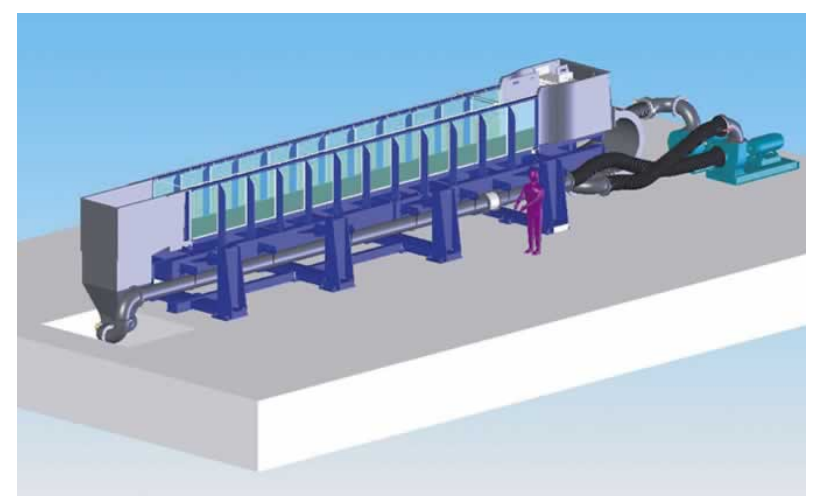

Figure 4: Flume

The equation for coefficient of discharge is defined as below: -

$$
Q=C_{d} \frac{2}{3} \sqrt{2 g} b H^{\frac{2}{3}}
$$

$\mathrm{Q}=$ Discharge

$\mathrm{C}_{\mathrm{d}}=$ Coefficient of Discharge

$\mathrm{g}=$ Acceleration of Gravity

$\mathrm{H}=$ The Head Loss

$\mathrm{b}=$ The Width of the Weir

The equation for coefficient of discharge is integration of the formula above. The integration are as follows: -

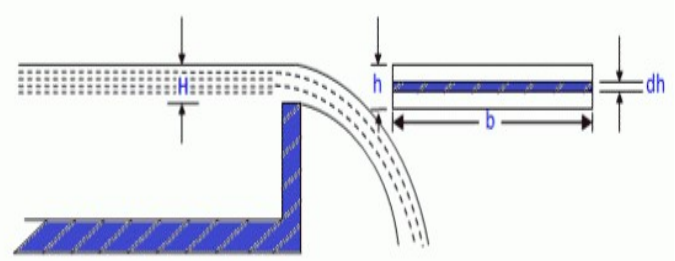

Figure 5: Rectangular Notch

The horizontal strip of water of thickness at a depth of $h$ from the water level $=\mathrm{dh}$

Area of the strip $=b . d h$

The theoretical velocity of water through the strip $=$ $\sqrt{2 g h}$

Discharge through the strip $=\mathrm{dq}$

$=\mathrm{C}_{\mathrm{d}} \times$ Area of Strip $\times$ Theorectical Velocity

$=\mathrm{C}_{\mathrm{d}} \cdot \mathrm{b} \mathrm{dh} \cdot \sqrt{2 g h}$

The total discharge over the whole notch can be found out by integrating the above equation within the limits 0 and $\mathrm{H}$.

$$
Q=C_{d \cdot} \cdot b \sqrt{2 g} \int_{0}^{H} h^{\frac{1}{2}} \cdot d h
$$

\subsection{Coefficient of Roughness}

The most common method used to determine the discharge rate in open channel is by using the Manning's equation. Manning's Roughness Coefficient, $\mathrm{n}$ is acting as the parameters that involve the water discharge, flow velocity, channel slope, channel roughness, water flow depth, and channel size and shape (Evangelos and Dimitrios,2016). There some conditions there also can be affecting the coefficient of roughness such as the channel properties, obstacle, undergrowth, silting and scouring.

Velocity profile in an open channel also determine by the height, velocity and the bed roughness. The $n$ value is the coefficient of roughness that applied to the uniform flow in open channels. However recent studies shown the coefficient of roughness are not constant.

Bed roughness is estimated by the Manning's Roughness Coefficient. Bed condition is one of the factors that can influence the discharge, Q and the roughness characteristics (Zheng and Shu qin,2012). In order to determine the coefficient of roughness, manning's equation has been studied in open channel conditions. However, there are still many unknown and uncertain factors that can affect the coefficient of roughness value in open channel hydraulics.

When water passing over land and channel, there are an amount of frictional resistance and it can be measure by hydraulic roughness. By using the manning equation, it can be used to find the coefficient of discharge in an open channel. The equations of the manning are as following: -

$$
\begin{aligned}
& \mathrm{v}=\frac{1}{\mathrm{n}} \mathrm{R}^{\frac{2}{3}} \mathrm{~S}^{\frac{1}{2}} \\
& \mathrm{R}=\frac{\mathrm{A}}{\mathrm{p}} \\
& \mathrm{Q}=\frac{\mathrm{A}}{\mathrm{n}} \mathrm{R}^{\frac{2}{3}} \mathrm{~S}^{\frac{1}{2}} \\
& n=\frac{1}{\mathrm{Q}} \mathrm{A} R^{\frac{2}{3}} \mathrm{~S}^{\frac{1}{2}}
\end{aligned}
$$

$\mathrm{Q}=$ Discharge,

$\mathrm{A}=$ Area of the channel,

$\mathrm{n}=$ coefficient of roughness (Manning coefficient),

$\mathrm{R}=$ Hydraulic Mean Depth

$\mathrm{S}=$ slope of the channel.

There are also many factors can affect the coefficient of the roughness such as the bed material, degree of 
channel, shape, size, channel obstructions, vegetation growing and the degree of meandering (Zarina And Ashikin,2011). By using different type of surface roughness and channel alignment, there will have different of manning coefficient value.

\section{Methodology}

In this study, an open channel is used to determine the coefficient of discharge and coefficient of roughness (Manning's Roughness Coefficient). There are many

parameters that can be controlled by the water flow in an open channel such as slope of the channel, the cross sectional area of the flow, the channel properties and resistance of flow. The objectives of this research are to study of coefficient of discharge and coefficient of roughness for lined and unlined channel.

There were two types of bed material were used in this experiment, which is concrete bed (lined channel) and short grass (unlined channel). The concrete bed has a size of $480 \mathrm{~mm}$ length $220 \mathrm{~mm}$ width, and $100 \mathrm{~mm}$ height where the short grass (Zoysia) has a height of less than $30 \mathrm{~mm}$.

The short grass will be placed in a tray before fixing the tray in the flume. In the other hand, the concrete bed is placed directly into the flume.

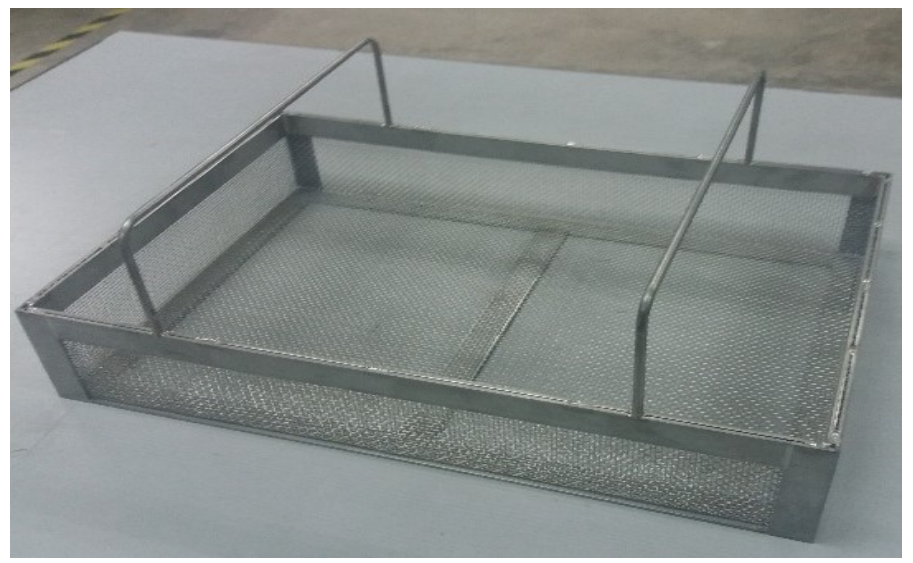

Figure 6: Tray

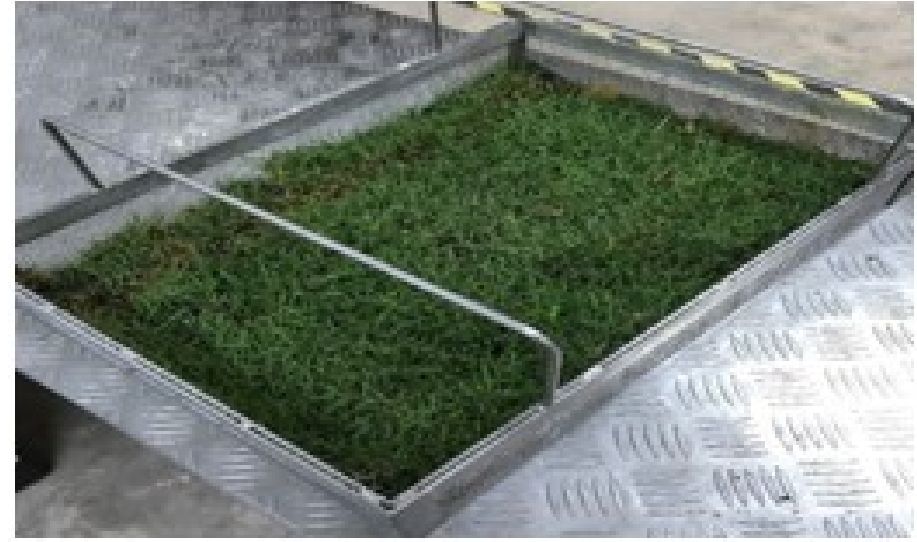

Figure 7: Short Grass

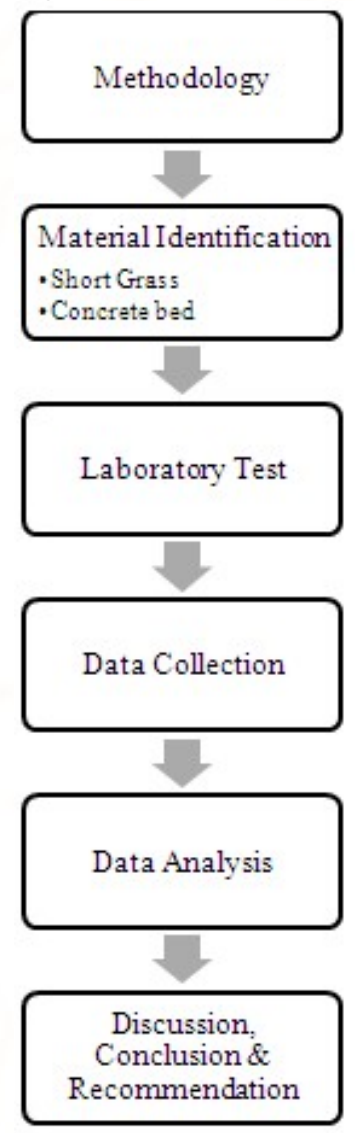

Figure 8: Flow Chart

\section{Results and Discussion}

Laboratory experiments were carried out in order to obtain the Coefficient of Discharge, $\mathrm{C}_{d}$ and Coefficient of Roughness (Manning's Roughness Coefficient), $n$. The experiments were carried out by using concrete bed and short grass (Zoysia) as bed materials.

Discharge rates used in this experiment are $20 \mathrm{~m}^{3} / \mathrm{h}$, $25 \mathrm{~m}^{3} / \mathrm{h}, 30 \mathrm{~m}^{3} / \mathrm{h}, 35 \mathrm{~m}^{3} / \mathrm{h}, 40 \mathrm{~m}^{3} / \mathrm{h}, 45 \mathrm{~m}^{3} / \mathrm{h}$ and 50 $\mathrm{m}^{3} / \mathrm{hr}$. On the other hand, the slope of the flume can be adjusted from 0 slope gradient which is $0^{\circ}$ (degree) to a maximum slope gradient of 3 which is $3^{\circ}$ (degree). 
4.1 Coefficient of Discharge for Lined Channel

A concrete bed was used as the bed material in this experiment. It has a size of $480 \mathrm{~mm}$ length, $220 \mathrm{~mm}$ width and $100 \mathrm{~mm}$ height. Slope gradient of 0 to 3 and Discharge, Q from $20 \mathrm{~m}^{3} / \mathrm{h}$ to $50 \mathrm{~m}^{3} / \mathrm{h}$ were used to obtain the values of height of water, $h$.
The values of the height of water were recorded in order to calculate the Theoretical Discharge, $\mathrm{Q}_{\mathrm{th}}$. Tables below shows the tabulated data and graphs were constructed according to the tables.

Table 4.1 shows the values obtained from the Slope Gradient $=0$

Table Error! No text of specified style in document..1 $\mathrm{Q}_{\text {th }}$ for concrete bed when $\mathrm{S}=0$

\begin{tabular}{|c|c|c|c|c|c|c|c|}
\hline $\mathbf{Q}(\mathrm{m} 3 / \mathrm{s})$ & $\mathbf{H}(\mathrm{m})$ & $\mathbf{b}(\mathbf{m})$ & $\mathbf{A}(\mathbf{m} 2)$ & $\mathbf{P}(\mathbf{m})$ & $\mathbf{R}(\mathbf{m})$ & $\mathbf{Q}(\mathbf{t h})$ & $\mathbf{C}_{d}$ \\
\hline 0.0056 & 0.1095 & 0.37 & 0.0845 & 0.8268 & 0.1022 & 0.2494 & 0.0223 \\
\hline 0.0069 & 0.1108 & 0.37 & 0.0851 & 0.8304 & 0.1025 & 0.2514 & 0.0276 \\
\hline 0.0083 & 0.1109 & 0.37 & 0.0852 & 0.8305 & 0.1025 & 0.2515 & 0.0331 \\
\hline 0.0097 & 0.1118 & 0.37 & 0.0856 & 0.8331 & 0.1028 & 0.2528 & 0.0385 \\
\hline 0.0111 & 0.1131 & 0.37 & 0.0863 & 0.8366 & 0.1031 & 0.2548 & 0.0436 \\
\hline 0.0125 & 0.1139 & 0.37 & 0.0867 & 0.8389 & 0.1033 & 0.2560 & 0.0488 \\
\hline 0.0139 & 0.1150 & 0.37 & 0.0873 & 0.8420 & 0.1036 & 0.2577 & 0.0539 \\
\hline
\end{tabular}

Table 4.2 shows the values obtained from the Slope Gradient $=1$

Table Error! No text of specified style in document. $2 \mathrm{Q}_{\mathrm{th}}$ for concrete bed when $\mathrm{S}=1$

\begin{tabular}{|c|c|c|c|c|c|c|c|}
\hline $\mathbf{Q}(\mathrm{m} 3 / \mathrm{s})$ & $\mathbf{H}(\mathrm{m})$ & $\mathbf{b}(\mathrm{m})$ & $\mathbf{A}(\mathrm{m} 2)$ & $\mathbf{P}(\mathrm{m})$ & $\mathbf{R}(\mathrm{m})$ & $\mathbf{Q}($ th $)$ & $\mathbf{C}_{d}$ \\
\hline 0.0056 & 0.1093 & 0.37 & 0.0403 & 0.5876 & 0.0686 & 0.2498 & 0.0222 \\
\hline 0.0069 & 0.1103 & 0.37 & 0.0407 & 0.5896 & 0.0690 & 0.2513 & 0.0276 \\
\hline 0.0083 & 0.1112 & 0.37 & 0.0410 & 0.5915 & 0.0694 & 0.2527 & 0.0330 \\
\hline 0.0097 & 0.1123 & 0.37 & 0.0414 & 0.5936 & 0.0698 & 0.2543 & 0.0382 \\
\hline 0.0111 & 0.1127 & 0.37 & 0.0416 & 0.5943 & 0.0699 & 0.2549 & 0.0436 \\
\hline 0.0125 & 0.1140 & 0.37 & 0.0421 & 0.5970 & 0.0705 & 0.2569 & 0.0487 \\
\hline 0.0139 & 0.1153 & 0.37 & 0.0426 & 0.5996 & 0.0710 & 0.2589 & 0.0537 \\
\hline
\end{tabular}

Table 4.3 shows the values obtained from the Slope Gradient $=2$

Table Error! No text of specified style in document..3 $\mathrm{Q}_{\mathrm{th}}$ for concrete bed when $\mathrm{S}=2$

\begin{tabular}{|c|c|c|c|c|c|c|c|}
\hline $\mathbf{Q}(\mathrm{m} 3 / \mathrm{s})$ & $\mathbf{H}(\mathbf{m})$ & $\mathbf{b}(\mathbf{m})$ & $\mathbf{A}(\mathrm{m} 2)$ & $\mathbf{P}(\mathbf{m})$ & $\mathbf{R}(\mathbf{m})$ & $\mathbf{Q}($ th $)$ & $\mathbf{C}_{d}$ \\
\hline 0.0056 & 0.1088 & 0.37 & 0.0401 & 0.5866 & 0.0684 & 0.2490 & 0.0223 \\
\hline 0.0069 & 0.1104 & 0.37 & 0.0407 & 0.5898 & 0.0691 & 0.2515 & 0.0276 \\
\hline 0.0083 & 0.1111 & 0.37 & 0.0410 & 0.5912 & 0.0693 & 0.2525 & 0.0330 \\
\hline 0.0097 & 0.1121 & 0.37 & 0.0413 & 0.5931 & 0.0697 & 0.2539 & 0.0383 \\
\hline 0.0111 & 0.1129 & 0.37 & 0.0416 & 0.5947 & 0.0700 & 0.2551 & 0.0435 \\
\hline 0.0125 & 0.1135 & 0.37 & 0.0419 & 0.5960 & 0.0703 & 0.2561 & 0.0488 \\
\hline 0.0139 & 0.1150 & 0.37 & 0.0424 & 0.5989 & 0.0708 & 0.2583 & 0.0538 \\
\hline
\end{tabular}

Table 4.4 shows the values obtained from the Slope Gradient $=3$

Table 4.4 Qth for concrete bed when $\mathrm{S}=3$

\begin{tabular}{|c|c|c|c|c|c|c|c|}
\hline $\mathbf{Q}(\mathbf{m} 3 / \mathrm{s})$ & $\mathbf{H}(\mathbf{m})$ & $\mathbf{b}(\mathbf{m})$ & $\mathbf{A}(\mathbf{m} 2)$ & $\mathbf{P}(\mathbf{m})$ & $\mathbf{R}(\mathbf{m})$ & $\mathbf{Q}($ th $)$ & $\mathbf{C}_{\mathrm{d}}$ \\
\hline 0.0056 & 0.1086 & 0.37 & 0.0401 & 0.5862 & 0.0684 & 0.2487 & 0.0223 \\
\hline 0.0069 & 0.1106 & 0.37 & 0.0408 & 0.5903 & 0.0692 & 0.2518 & 0.0276 \\
\hline
\end{tabular}


International Journal of Trend in Scientific Research and Development (IJTSRD) | ISSN: 2456-647

\begin{tabular}{|l|l|l|l|l|l|l|l|}
\hline 0.0083 & 0.1114 & 0.37 & 0.0411 & 0.5919 & 0.0695 & 0.2530 & 0.0329 \\
\hline 0.0097 & 0.1125 & 0.37 & 0.0415 & 0.5940 & 0.0699 & 0.2546 & 0.0382 \\
\hline 0.0111 & 0.1139 & 0.37 & 0.0420 & 0.5968 & 0.0704 & 0.2567 & 0.0433 \\
\hline 0.0125 & 0.1146 & 0.37 & 0.0423 & 0.5982 & 0.0707 & 0.2578 & 0.0485 \\
\hline 0.0139 & 0.1151 & 0.37 & 0.0425 & 0.5992 & 0.0709 & 0.2585 & 0.0537 \\
\hline
\end{tabular}

From tables above, the result shows that the range of coefficient of discharge, $\mathrm{C}_{\mathrm{d}}$ values are from 0.0222 to 0.0539 . Slope gradient, $S=1$ has the lowest coefficient of discharge, $C_{d}$ at discharge rate, $Q=20 \mathrm{~m}^{3} / \mathrm{h}$ and Slope gradient, $S=3$ has the highest coefficient of discharge, $C_{d}$ at discharge rate, $Q=50 \mathrm{~m}^{3} / \mathrm{hr}$.

The calculated value of coefficient of discharge, $\mathrm{C}_{\mathrm{d}}$ are similar for slope gradient, $\mathrm{S}$ from 0 to 3 at discharge, $\mathrm{Q}$ $=20 \mathrm{~m}^{3} / \mathrm{s}$. This is due to the significant affect to coefficient of discharge are caused by discharge rate. Therefore, the higher the discharge rate, the higher the coefficient of discharge.

\subsection{Coefficient of Discharge for Unlined Channel}

In this experiment, the type of short grass used as the bed material is Zoysia grass. It is less than $30 \mathrm{~mm}$ in height. Slope gradient of 1 to 3 and Discharge, Q from $20 \mathrm{~m}^{3} / \mathrm{h}$ to $50 \mathrm{~m}^{3} / \mathrm{h}$ were used to obtain the values of height of water, h.

The values of the height of water were recorded in order to calculate the Theoretical Discharge, $\mathrm{Q}_{\text {th }}$. Tables below shows the tabulated data and graphs were constructed according to the tables

Table 4.5 shows the values obtained from the Slope Gradient $=0$

Table Error! No text of specified style in document..4 $\mathrm{Q}_{\text {th }}$ for short grass when $\mathrm{S}=0$

\begin{tabular}{|c|c|c|c|c|c|c|c|c|}
\hline $\mathbf{Q}(\mathbf{m} 3 / \mathrm{s})$ & $\mathbf{H}(\mathbf{m})$ & $\mathbf{b}(\mathbf{m})$ & $\mathbf{A}(\mathbf{m} 2)$ & $\mathbf{P}(\mathbf{m})$ & $\mathbf{R}(\mathbf{m})$ & $\mathbf{S}$ & $\mathbf{Q}(\mathbf{t h})$ & $\mathbf{C}_{\mathrm{d}}$ \\
\hline 0.0056 & 0.1124 & 0.37 & 0.0859 & 0.8347 & 0.1029 & 0.0000 & 0.2544 & 0.0218 \\
\hline 0.0069 & 0.1181 & 0.37 & 0.0888 & 0.8505 & 0.1045 & 0.0000 & 0.2630 & 0.0264 \\
\hline 0.0083 & 0.1301 & 0.37 & 0.0948 & 0.8826 & 0.1074 & 0.0000 & 0.2806 & 0.0297 \\
\hline 0.0097 & 0.1393 & 0.37 & 0.0992 & 0.9065 & 0.1094 & 0.0000 & 0.2936 & 0.0331 \\
\hline 0.0111 & 0.1421 & 0.37 & 0.1005 & 0.9137 & 0.1100 & 0.0000 & 0.2976 & 0.0373 \\
\hline 0.0125 & 0.1481 & 0.37 & 0.1033 & 0.9287 & 0.1112 & 0.0000 & 0.3058 & 0.0409 \\
\hline 0.0139 & 0.1544 & 0.37 & 0.1062 & 0.9445 & 0.1124 & 0.0000 & 0.3144 & 0.0442 \\
\hline
\end{tabular}

Table 4.6 shows the values obtained from the Slope Gradient $=1$

Table Error! No text of specified style in document. .5 $\mathrm{Q}_{\text {th }}$ for short grass when $\mathrm{S}=1$

\begin{tabular}{|c|c|c|c|c|c|c|c|c|}
\hline $\mathbf{Q}(\mathbf{m} 3 / \mathrm{s})$ & $\mathbf{H}(\mathbf{m})$ & $\mathbf{b}(\mathbf{m})$ & $\mathbf{A}(\mathbf{m} 2)$ & $\mathbf{P}(\mathbf{m})$ & $\mathbf{R}(\mathbf{m})$ & $\mathbf{S}$ & $\mathbf{Q}(\mathbf{t h})$ & $\mathbf{C}_{\mathbf{d}}$ \\
\hline 0.0056 & 0.1044 & 0.37 & 0.0385 & 0.5777 & 0.0667 & 0.1304 & 0.2422 & 0.0229 \\
\hline 0.0069 & 0.1135 & 0.37 & 0.0419 & 0.5960 & 0.0703 & 0.1304 & 0.2561 & 0.0271 \\
\hline 0.0083 & 0.1275 & 0.37 & 0.0470 & 0.6240 & 0.0754 & 0.1304 & 0.2768 & 0.0301 \\
\hline 0.0097 & 0.1340 & 0.37 & 0.0494 & 0.6370 & 0.0776 & 0.1304 & 0.2861 & 0.0340 \\
\hline 0.0111 & 0.1432 & 0.37 & 0.0528 & 0.6553 & 0.0806 & 0.1304 & 0.2990 & 0.0372 \\
\hline 0.0125 & 0.1488 & 0.37 & 0.0549 & 0.6666 & 0.0824 & 0.1304 & 0.3068 & 0.0407 \\
\hline 0.0139 & 0.1522 & 0.37 & 0.0562 & 0.6735 & 0.0834 & 0.1304 & 0.3115 & 0.0446 \\
\hline
\end{tabular}

Table 4.7 shows the values obtained from the Slope Gradient $=2$

Table Error! No text of specified style in document..6 $Q_{\text {th }}$ for short grass when $S=2$

\begin{tabular}{|c|c|c|c|c|c|c|c|c|}
\hline $\mathbf{Q}(\mathbf{m} 3 / \mathbf{s})$ & $\mathbf{H}(\mathbf{m})$ & $\mathbf{b}(\mathbf{m})$ & $\mathbf{A}(\mathbf{m} 2)$ & $\mathbf{P}(\mathbf{m})$ & $\mathbf{R}(\mathbf{m})$ & $\mathbf{S}$ & $\mathbf{Q}(\mathbf{t h})$ & $\mathbf{C}_{\mathbf{d}}$ \\
\hline 0.0056 & 0.1077 & 0.37 & 0.0397 & 0.5843 & 0.0680 & 0.1304 & 0.2473 & 0.0225 \\
\hline 0.0069 & 0.1163 & 0.37 & 0.0429 & 0.6016 & 0.0713 & 0.1304 & 0.2603 & 0.0267 \\
\hline 0.0083 & 0.1262 & 0.37 & 0.0466 & 0.6214 & 0.0749 & 0.1304 & 0.2749 & 0.0303 \\
\hline
\end{tabular}


International Journal of Trend in Scientific Research and Development (IJTSRD) | ISSN: 2456-647

\begin{tabular}{|l|l|l|l|l|l|l|l|l|}
\hline 0.0097 & 0.1365 & 0.37 & 0.0504 & 0.6420 & 0.0785 & 0.1304 & 0.2897 & 0.0336 \\
\hline 0.0111 & 0.1415 & 0.37 & 0.0522 & 0.6521 & 0.0801 & 0.1304 & 0.2967 & 0.0374 \\
\hline 0.0125 & 0.1486 & 0.37 & 0.0548 & 0.6663 & 0.0823 & 0.1304 & 0.3066 & 0.0408 \\
\hline 0.0139 & 0.1521 & 0.37 & 0.0561 & 0.6732 & 0.0834 & 0.1304 & 0.3113 & 0.0446 \\
\hline
\end{tabular}

Table 4.8 shows the values obtained from the Slope Gradient $=3$

Table Error! No text of specified style in document..7 $Q_{\text {th }}$ for short grass when $\mathrm{S}=3$

\begin{tabular}{|c|c|c|c|c|c|c|c|c|}
\hline $\mathrm{Q}(\mathrm{m} 3 / \mathrm{s})$ & $\mathrm{H}(\mathrm{m})$ & $\mathrm{b}(\mathrm{m})$ & $\mathrm{A}(\mathrm{m} 2)$ & $\mathrm{P}(\mathrm{m})$ & $\mathrm{R}(\mathrm{m})$ & $\mathrm{S}$ & $\mathrm{Q}(\mathrm{th})$ & $\mathrm{C}_{\mathrm{d}}$ \\
\hline 0.0056 & 0.1129 & 0.37 & 0.0417 & 0.5949 & 0.0701 & 0.1304 & 0.2553 & 0.0218 \\
\hline 0.0069 & 0.1217 & 0.37 & 0.0449 & 0.6123 & 0.0733 & 0.1304 & 0.2683 & 0.0259 \\
\hline 0.0083 & 0.1307 & 0.37 & 0.0482 & 0.6304 & 0.0765 & 0.1304 & 0.2814 & 0.0296 \\
\hline 0.0097 & 0.1357 & 0.37 & 0.0501 & 0.6404 & 0.0782 & 0.1304 & 0.2886 & 0.0337 \\
\hline 0.0111 & 0.1433 & 0.37 & 0.0529 & 0.6555 & 0.0806 & 0.1304 & 0.2991 & 0.0371 \\
\hline 0.0125 & 0.1486 & 0.37 & 0.0548 & 0.6661 & 0.0823 & 0.1304 & 0.3065 & 0.0408 \\
\hline 0.0139 & 0.1511 & 0.37 & 0.0558 & 0.6712 & 0.0831 & 0.1304 & 0.3100 & 0.0448 \\
\hline
\end{tabular}

Tables above shows the range of coefficient of discharge, $\mathrm{C}_{\mathrm{d}}$ for different slope gradient. Values obtained ranges from 0.0218 to 0.0448 . Slope gradient, $\mathrm{S}=0$ and 3 has the lowest coefficient of discharge, $C_{d}$ at discharge, $\mathrm{Q}=20 \mathrm{~m}^{3} / \mathrm{hr}$ and Slope gradient, $\mathrm{S}=3$ has the highest coefficient of discharge, $\mathrm{C}_{\mathrm{d}}$ at discharge, $\mathrm{Q}=$ $50 \mathrm{~m}^{3} / \mathrm{hr}$.

The calculated value of coefficient of discharge, $C_{d}$ are similar for slope gradient, $S$ from 0 to 3 . This is due to the significant affect to coefficient of discharge are caused by discharge. Therefore, the higher the discharge, the higher the coefficient of discharge.

\subsection{Coefficient of Roughness}

Manning equation is the most common method that used to determine the flow rate in an open channel. It involves the discharge, velocity, channel slope, channel roughness, water flow depth and channel size and shape. Coefficient of roughness are mostly determined by using Manning's equation

\subsection{Coefficient of Roughness for Lined Channel}

A concrete bed was used as the bed material in this experiment. It has a size of $480 \mathrm{~mm}$ length, $220 \mathrm{~mm}$ width and $100 \mathrm{~mm}$ height. Slope gradient of 1 to 3 and Discharge, Q from $20 \mathrm{~m}^{3} / \mathrm{h}$ to $50 \mathrm{~m}^{3} / \mathrm{h}$ were used to obtain the values of height of water, $h$.

The values of the height of water were recorded in order to calculate the Manning's Coefficient of Roughness. Tables below shows the tabulated data and graphs were constructed according to the tables

Table Error! No text of specified style in document..8 $\mathrm{n}$ value for concrete bed when $\mathrm{S}=1$

\begin{tabular}{|c|c|c|c|c|c|c|}
\hline $\mathbf{Q}(\mathbf{m} 3 / \mathbf{s})$ & $\mathbf{H}(\mathbf{m})$ & $\mathbf{b}(\mathbf{m})$ & $\mathbf{A}(\mathbf{m} 2)$ & $\mathbf{P}(\mathbf{m})$ & $\mathbf{R}(\mathbf{m})$ & $\mathbf{n}$ \\
\hline 0.0056 & 0.1093 & 0.37 & 0.0403 & 0.5876 & 0.0686 & 0.1587 \\
\hline 0.0069 & 0.1103 & 0.37 & 0.0407 & 0.5896 & 0.0690 & 0.1286 \\
\hline 0.0083 & 0.1112 & 0.37 & 0.0410 & 0.5915 & 0.0694 & 0.1084 \\
\hline 0.0097 & 0.1123 & 0.37 & 0.0414 & 0.5936 & 0.0698 & 0.0942 \\
\hline 0.0111 & 0.1127 & 0.37 & 0.0416 & 0.5943 & 0.0699 & 0.0828 \\
\hline 0.0125 & 0.1140 & 0.37 & 0.0421 & 0.5970 & 0.0705 & 0.0749 \\
\hline 0.0139 & 0.1153 & 0.37 & 0.0426 & 0.5996 & 0.0710 & 0.0685 \\
\hline
\end{tabular}

Table Error! No text of specified style in document..9 $\mathrm{n}$ value for concrete bed when $\mathrm{S}=2$

\begin{tabular}{|c|c|c|c|c|c|c|}
\hline $\mathbf{Q}(\mathbf{m} 3 / \mathrm{s})$ & $\mathbf{H}(\mathbf{m})$ & $\mathbf{b}(\mathbf{m})$ & $\mathbf{A}(\mathbf{m} 2)$ & $\mathbf{P}(\mathbf{m})$ & $\mathbf{R}(\mathbf{m})$ & $\mathbf{n}$ \\
\hline 0.0056 & 0.1088 & 0.37 & 0.0401 & 0.5866 & 0.0684 & 0.2262 \\
\hline
\end{tabular}


International Journal of Trend in Scientific Research and Development (IJTSRD) | ISSN: 2456-647

\begin{tabular}{|l|l|l|l|l|l|l|}
\hline 0.0069 & 0.1104 & 0.37 & 0.0407 & 0.5898 & 0.0691 & 0.1848 \\
\hline 0.0083 & 0.1111 & 0.37 & 0.0410 & 0.5912 & 0.0693 & 0.1554 \\
\hline 0.0097 & 0.1121 & 0.37 & 0.0413 & 0.5931 & 0.0697 & 0.1348 \\
\hline 0.0111 & 0.1129 & 0.37 & 0.0416 & 0.5947 & 0.0700 & 0.1191 \\
\hline 0.0125 & 0.1135 & 0.37 & 0.0419 & 0.5960 & 0.0703 & 0.1068 \\
\hline 0.0139 & 0.1150 & 0.37 & 0.0424 & 0.5989 & 0.0708 & 0.0978 \\
\hline
\end{tabular}

Table Error! No text of specified style in document..10 $\mathrm{n}$ value for concrete bed when $\mathrm{S}=3$

\begin{tabular}{|c|c|c|c|c|c|c|}
\hline $\mathbf{Q}(\mathbf{m} 3 / \mathbf{s})$ & $\mathbf{H}(\mathbf{m})$ & $\mathbf{b}(\mathbf{m})$ & $\mathbf{A}(\mathbf{m} 2)$ & $\mathbf{P}(\mathbf{m})$ & $\mathbf{R}(\mathbf{m})$ & $\mathbf{n}$ \\
\hline 0.0056 & 0.1086 & 0.37 & 0.0401 & 0.5862 & 0.0684 & 0.2662 \\
\hline 0.0069 & 0.1106 & 0.37 & 0.0408 & 0.5903 & 0.0692 & 0.2187 \\
\hline 0.0083 & 0.1114 & 0.37 & 0.0411 & 0.5919 & 0.0695 & 0.1841 \\
\hline 0.0097 & 0.1125 & 0.37 & 0.0415 & 0.5940 & 0.0699 & 0.1600 \\
\hline 0.0111 & 0.1139 & 0.37 & 0.0420 & 0.5968 & 0.0704 & 0.1424 \\
\hline 0.0125 & 0.1146 & 0.37 & 0.0423 & 0.5982 & 0.0707 & 0.1277 \\
\hline 0.0139 & 0.1151 & 0.37 & 0.0425 & 0.5992 & 0.0709 & 0.1156 \\
\hline
\end{tabular}

Tables above shows the range of Manning's coefficient of roughness, $\mathrm{n}$ for different slope gradient. Values obtained ranges from 0.0683 to 0.2262 . Slope gradient, $S=1$ has the lowest Manning's coefficient of roughness at discharge, $\mathrm{Q}=50 \mathrm{~m}^{3} / \mathrm{hr}$ and Slope gradient, $\mathrm{S}=3$ has the highest Manning's coefficient of roughness, $\mathrm{n}$ at discharge, $\mathrm{Q}=20 \mathrm{~m}^{3} / \mathrm{hr}$.

Therefore, the higher the Manning's Coefficient of Roughness, the lower the discharge.

\subsection{Coefficient of Roughness for Unlined Channel}

In this experiment, the type of short grass used as the bed material is Zoysia grass. It is less than $30 \mathrm{~mm}$ in height. Slope gradient of 1 to 3 and Discharge, Q from $20 \mathrm{~m}^{3} / \mathrm{h}$ to $50 \mathrm{~m}^{3} / \mathrm{h}$ were used to obtain the values of height of water, $h$.

The values of the height of water were recorded in order to calculate the Manning's Coefficient of Roughness. Tables below shows the tabulated data and graphs were constructed according to the tables

Table Error! No text of specified style in document.. $11 \mathrm{n}$ values for short grass when $\mathrm{S}=1$

\begin{tabular}{|c|c|c|c|c|c|c|}
\hline $\mathbf{Q}(\mathbf{m} 3 / \mathbf{s})$ & $\mathbf{H}(\mathbf{m})$ & $\mathbf{b}(\mathbf{m})$ & $\mathbf{A}(\mathbf{m} 2)$ & $\mathbf{P}(\mathbf{m})$ & $\mathbf{R}(\mathbf{m})$ & $\mathbf{n}$ \\
\hline 0.0056 & 0.1044 & 0.37 & 0.0385 & 0.5777 & 0.0667 & 0.1486 \\
\hline 0.0069 & 0.1135 & 0.37 & 0.0419 & 0.5960 & 0.0703 & 0.1339 \\
\hline 0.0083 & 0.1275 & 0.37 & 0.0470 & 0.6240 & 0.0754 & 0.1313 \\
\hline 0.0097 & 0.1340 & 0.37 & 0.0494 & 0.6370 & 0.0776 & 0.1207 \\
\hline 0.0111 & 0.1432 & 0.37 & 0.0528 & 0.6553 & 0.0806 & 0.1157 \\
\hline 0.0125 & 0.1488 & 0.37 & 0.0549 & 0.6666 & 0.0824 & 0.1084 \\
\hline 0.0139 & 0.1522 & 0.37 & 0.0562 & 0.6735 & 0.0834 & 0.1007 \\
\hline
\end{tabular}

Table Error! No text of specified style in document..12 n values for short grass when $\mathrm{S}=2$

\begin{tabular}{|c|c|c|c|c|c|c|}
\hline $\mathbf{Q}(\mathbf{m} 3 / \mathbf{s})$ & $\mathbf{H}(\mathbf{m})$ & $\mathbf{b}(\mathbf{m})$ & $\mathbf{A}(\mathbf{m} 2)$ & $\mathbf{P}(\mathbf{m})$ & $\mathbf{R}(\mathbf{m})$ & $\mathbf{n}$ \\
\hline 0.0056 & 0.1077 & 0.37 & 0.0397 & 0.5843 & 0.0680 & 0.2229 \\
\hline 0.0069 & 0.1163 & 0.37 & 0.0429 & 0.6016 & 0.0713 & 0.1989 \\
\hline 0.0083 & 0.1262 & 0.37 & 0.0466 & 0.6214 & 0.0749 & 0.1858 \\
\hline 0.0097 & 0.1365 & 0.37 & 0.0504 & 0.6420 & 0.0785 & 0.1777 \\
\hline 0.0111 & 0.1415 & 0.37 & 0.0522 & 0.6521 & 0.0801 & 0.1634 \\
\hline 0.0125 & 0.1486 & 0.37 & 0.0548 & 0.6663 & 0.0823 & 0.1554 \\
\hline 0.0139 & 0.1521 & 0.37 & 0.0561 & 0.6732 & 0.0834 & 0.1443 \\
\hline
\end{tabular}

Table Error! No text of specified style in document. $13 \mathrm{n}$ values for short grass when $\mathrm{S}=3$

\begin{tabular}{|c|c|c|c|c|c|c|}
\hline $\mathbf{Q}(\mathbf{m} 3 / \mathbf{s})$ & $\mathbf{H}(\mathbf{m})$ & $\mathbf{b}(\mathbf{m})$ & $\mathbf{A}(\mathbf{m} 2)$ & $\mathbf{P}(\mathbf{m})$ & $\mathbf{R}(\mathbf{m})$ & $\mathbf{n}$ \\
\hline 0.0056 & 0.1129 & 0.37 & 0.0417 & 0.5949 & 0.0701 & 0.2815 \\
\hline
\end{tabular}




\begin{tabular}{|l|l|l|l|l|l|l|}
\hline 0.0069 & 0.1217 & 0.37 & 0.0449 & 0.6123 & 0.0733 & 0.2500 \\
\hline 0.0083 & 0.1307 & 0.37 & 0.0482 & 0.6304 & 0.0765 & 0.2303 \\
\hline 0.0097 & 0.1357 & 0.37 & 0.0501 & 0.6404 & 0.0782 & 0.2080 \\
\hline 0.0111 & 0.1433 & 0.37 & 0.0529 & 0.6555 & 0.0806 & 0.1961 \\
\hline 0.0125 & 0.1486 & 0.37 & 0.0548 & 0.6661 & 0.0823 & 0.1832 \\
\hline 0.0139 & 0.1511 & 0.37 & 0.0558 & 0.6712 & 0.0831 & 0.1688 \\
\hline
\end{tabular}

Tables above shows the range of Manning's coefficient of Roughness, $\mathrm{n}$ for different slope gradient. Values obtained ranges from 0.1007 to 0.2815 . Slope gradient, $\mathrm{S}=1$ has the lowest Manning's coefficient of roughness, $\mathrm{n}$ at discharge, $\mathrm{Q}=50 \mathrm{~m}^{3} / \mathrm{hr}$ and Slope gradient, $\mathrm{S}=3$ has the highest Manning's coefficient of roughness, $\mathrm{n}$ at discharge, $\mathrm{Q}=20 \mathrm{~m}^{3} / \mathrm{h}$.

Therefore, the higher the Manning's Coefficient of Roughness, the lower the discharge.

\subsection{Comparison Discharge Vs Manning's Roughness}

Graph Discharge vs Manning's Coefficient of Roughness for concrete bed and short grass for different slope gradient were constructed according to the tabulated data from the tables above.

\section{$S=1$}

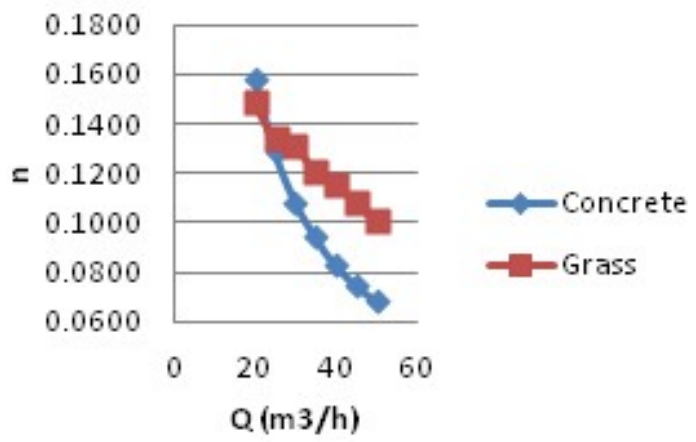

Figure 2 Graph Showing Discharge vs Manning's Coefficient of Roughness when $\mathrm{S}=1$

$$
\mathrm{S}=\mathbf{2}
$$

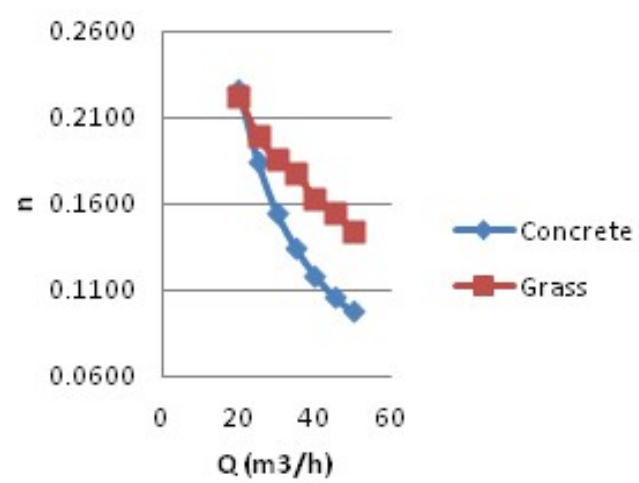

Figure 3 Graph Showing Discharge vs Manning's Coefficient of Roughness when $\mathrm{S}=2$

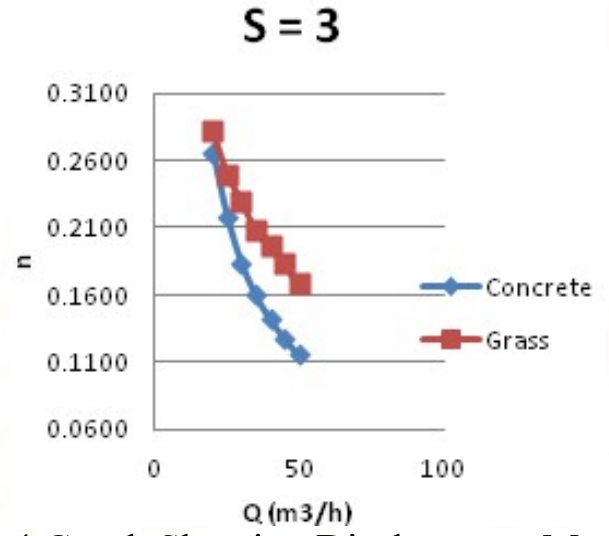

Figure 4 Graph Showing Discharge vs Manning's

Coefficient of Roughness when $\mathrm{S}=3$

From the graphs above, Manning's Coefficient Roughness value are highest at the discharge of $20 \mathrm{~m}^{3} / \mathrm{s}$ and lowest at the discharge of $50 \mathrm{~m}^{3} / \mathrm{s}$. Short grass has higher Manning's Coefficient Roughness value than concrete bed.

Graph Discharge Vs Hydraulic Mean Depth for concrete bed and short grass for different slope gradient were constructed according to the tabulated data from the tables above.

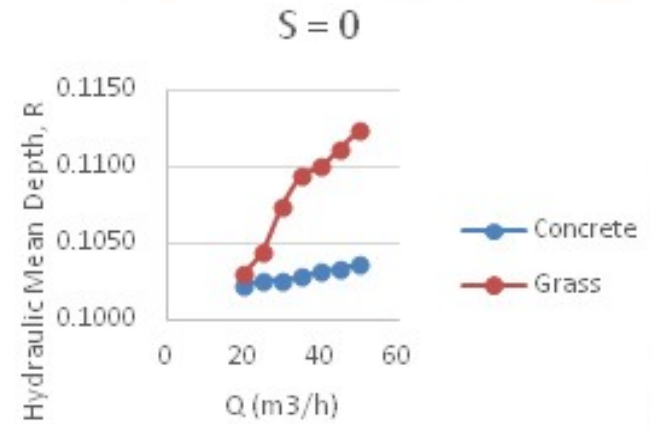

Figure Error! No text of specified style in

document..5 Graph showing Discharge vs Hydraulic Mean Depth when $\mathrm{S}=0$ 


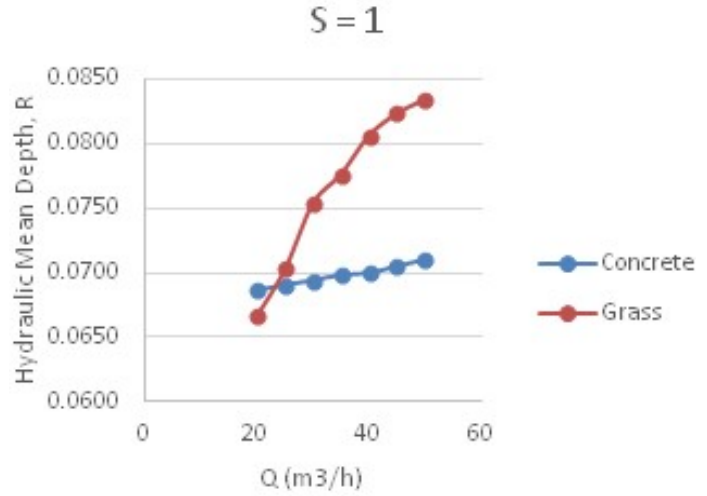

Figure Error! No text of specified style in document..6 Graph showing Discharge vs Hydraulic Mean Depth when $S=1$

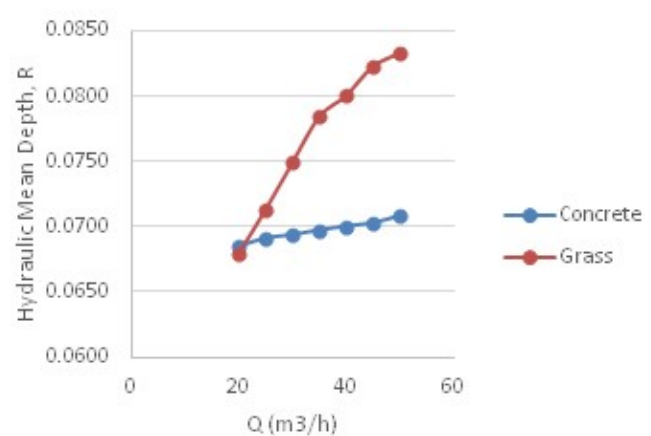

Figure Error! No text of specified style in document..7 Graph showing Discharge vs Hydraulic Mean Depth when $\mathrm{S}=2$ $S=3$

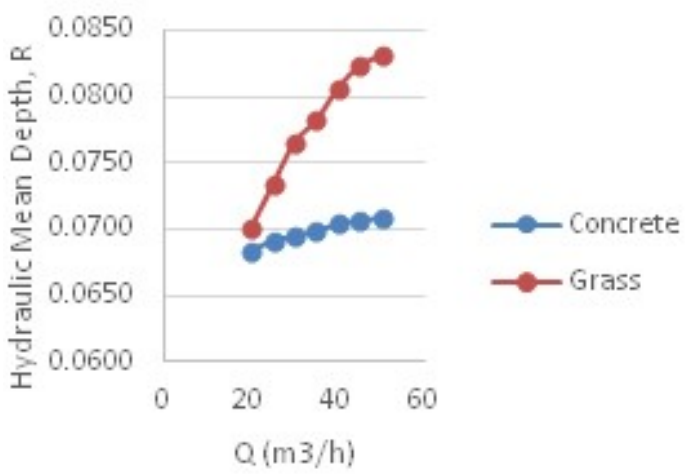

Figure Error! No text of specified style in document..8 Graph showing Discharge vs Hydraulic Mean Depth when $\mathrm{S}=3$

Graph Discharge Vs Hydraulic Mean Depth shows that the Hydraulic Mean Depth increase as the discharge increase. Therefore, Hydraulic Mean Depth is increasing directly proportional to discharge.

\section{Conclusion}

The Coefficient of Discharge value, $C_{d}$ for rectangular notch found in this study are in the range of 0.0222 to 0.0528 , where both are lower than the theoretical values with $C_{d}$ value of 0.57 to 0.9 .
The Manning's Coefficient of Roughness value, $\mathrm{n}$ found in this study are in the range of 0.1007 to 0.2815 for short grass and 0.0685 to 0.2662 for concrete bed, where both of the values are 0.045 to 0.07 for short grass and 0.015 to 0.02 for concrete bed in theoretical value.

In conclusion, the coefficient of discharge and coefficient of roughness are determined for lined channel (concrete) and unlined channel (short grass). The results showed significant items that are shown below-

1. The coefficient of discharge is directly proportional to discharge.

2. The discharge is decreasing when the coefficient of roughness (Manning's roughness coefficient) is increasing.

3. The discharge is directly proportional to hydraulic mean depth.

The findings obtained from the experiment are as follows: -,

1. Concrete bed has higher coefficient of discharge than short grass

2. Short grass has higher coefficient of roughness than concrete bed.

3. The value of coefficient of discharge is directly proportional to discharge. The larger value of discharge, larger the coefficient of discharge.

4. Coefficient of roughness (Manning's Coefficient of Roughness) increase, the discharge decrease.

5. Type of bed materials affect the coefficient of roughness.

6. The slope gradient does not affect the coefficient of discharge and coefficient of roughness (Manning's Coefficient of Roughness).

7. Discharge is directly proportional to Hydraulic Mean Depth.

\section{REFERENCES}

1. Aldridge, B. N., and Garrett, J. M. (1973). Roughness Coefficients for Stream Channels in Arizona. U.S. Geological Survey Open-File Report, 86-89 p

2. Chow, V. T. (1959). Open Channel Hydraulics. McGraw-Hill Bok Company. New York.

3. Department of Irrigation and Drainage (DID). (2012). Urban Stormwater Management Manual for Malaysia. 2nd Edition. Government of Malaysia. 
4. Ding, Y., Jia, Y. and Wang S. S. Y. (2004). Identification of Manning's Roughness Coefficient in Shallow Water Flows. Journal of Hydraulic Engineering, ASCE, 502-509.

5. Evangelos Hatzigiannakis, Dimitrios Pantelakis Ioannis Hatzispiroglo, George Arampatzis, Andreas Ilias1, Andreas Panagopoulos (2016), Discharge Measurements and Roughness Coefficient Estimation in a River, Environ. Process, 263-266

6. Jisung Kim, Won Kim, Chanjoo Lee, Yong Jeon Kim (2010), Roughness coefficient and its Uncertainty, Water Science And Engineering, vol $3,217-232$

7. Kiumars Badr, Dariush Mowla (2014), Development of Rectangular Broad-crested Weirs for Flow Characteristics and Discharge Measurement, KSCE Journal Of Civil Engineering, 19(1), 136-141

8. Limerinos J. T. (1970), Determination of the Manning Coefficient From Measured Bed Roughness in Natural Channels, U.S. Geological Survey Water-Supply Paper, B2-B13
9. N Mustaffa, N A Ahmad1, M A M Razil (2016), Variations of Roughness Coefficients with Flow Depth of Grassed Swale, IOP Publishing, 1-3

10. Shambo M. T, Deepak T. J., Joyce Edwin Bategeleza, Abdulhakeem Nasir (2015), Determining Coefficient of Discharge to Compare Coefficients of Resistance for Different Coarse Aggregate Beds, IJSRSET, 1 (4), 468-472

11. Viessman, W. and L. Lewis. (1996). Introduction to Hydrology, 4th ed. Harper Collins College Publishers, New York.

12. Zarina Md Ali, Nor Ashikin Saib (2011), Influence of Bed Roughness In Open Channel, Proceeding of International Seminar on Application of Science Matehmatics, 1-3

13. Zi-cheng ZHENG, Shu-qin HE, Fa-qi WU (2012), Relationship between soil surface roughness and hydraulic roughness coefficient on sloping farmland, Water Science and Engineering, 5(2), 191-201 